\title{
ACUTE NITRATE EXPOSURE CAUSES PROTEOMIC CHANGES CONSISTENT \\ WITH THE REGULATION OF REACTIVE OXYGEN AND NITROGEN SPECIES \\ IN THE PACIFIC OYSTER, CRASSOSTREA GIGAS
}

\author{
A Thesis \\ presented to \\ the Faculty of California Polytechnic State University, \\ San Luis Obispo
}

\author{
In Partial Fulfillment \\ of the Requirements for the Degree \\ Master of Science in Biological Sciences
}

by

Lauren R. Hitt

June 2009 
(C) 2009

Lauren R. Hitt

ALL RIGHTS RESERVED 
TITLE:
AUTHOR:
DATE SUBMITTED:
June 2009
Lauren R. Hitt
Lars Tomanek, Assistant Professor
Nikki Adams, Associate Professor

\section{ACUTE NITRATE EXPOSURE CAUSES A \\ PROTEOMIC RESPONSE TO REACTIVE \\ NITROGEN SPECIES IN THE PACIFIC \\ OYSTER, CRASSOSTREA GIGAS}

COMMITTEE MEMBER: Royden Nakamura, Professor 


\begin{abstract}
ACUTE NITRATE EXPOSURE CAUSES A PROTEOMIC RESPONSE TO REACTIVE NITROGEN SPECIES IN THE PACIFIC OYSTER, CRASSOSTREA GIGAS
\end{abstract}

Lauren R. Hitt

Nitrate is the most common ionic form of nitrogen in aquatic ecosystems. Although nitrate is known to affect ecosystems at high levels through eutrophication, hypoxia and loss of biodiversity, it is considered to be physiologically inert to the individual aquatic organism. To test the physiological effects of nitrate on aquatic life, we exposed gill tissue of the Pacific oyster, Crassostrea gigas, to nitrate and characterized changes in protein expression, using a gel-based proteomics approach. Of the 642 protein spots detected, we found that 24 proteins ( 15 identified) changed expression in response to a 6-hour exposure to nitrate concentrations ranging from 0-73 $\mathrm{mg} / \mathrm{L}$, values that characterize highly contaminated surface and ground waters. Proteins changing expression included the oxidative stress proteins thioredoxin and cavortin (a member of the superoxide dismutase family) as well as proteins that are involved in G-protein signaling (RhoGDI, ADP-ribosylation factor, G-protein ß-subunit), protein homeostasis (heat shock protein 70, prohibitin, calreticulin, and proteasome $\alpha$-type 4 subunit), glycolysis (enolase), transport of hydrophobic molecules (lipocalin) and cytoskeletal arrangements (intermediate filaments and a gelsolin-like adseverin). The most parsimonious explanation for these changes in protein expression assumes that $C$. gigas reduces nitrate to nitrite and nitric oxide, which reacts with superoxide anions to form the very reactive peroxynitrite. We propose that part of the cellular response to reactive nitrogen species, phagocytic hemocytes inhibit the production of reactive oxygen species, potentially compromising the immune response of oysters to invading pathogens. 


\section{ACKNOWLEDGEMENTS}

This work was made possible through the support of the David and Lucile Packard Foundation and the Resource Legacy Foundation to the San Luis Obispo Science and Ecosystem Alliance (SLOSEA), a consortium of scientists and ecosystem stakeholders. We thank the members of the SLOSEA advisory committee for challenging us to investigate this question and for their interest in our work. We would like to thank the Tomales Bay Oyster Company for generously donating oysters for this project.

I would like to personally thank my thesis committee, Lars Tomanek, Nikki Adams, and Royden Nakamura, for their wonderful input and sincere advice throughout the completion of this project. Their time and efforts have been greatly appreciated. 
I. CHAPTER ONE: INTRODUCTION TO MANUSCRIPT ..................... 1

Nitrogen cycle...............................................

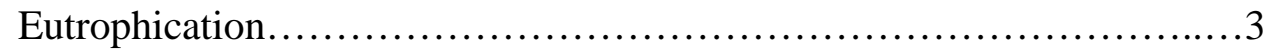

Morro Bay...................................................

Toxicity of nitrate............................................. 5

Crassostrea gigas..............................................

Proteomics................................................. 8

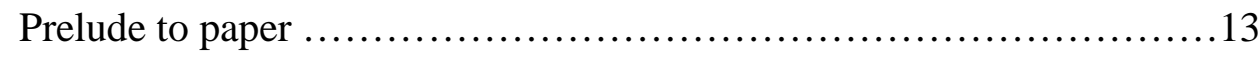

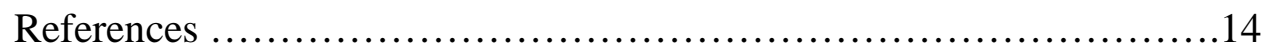

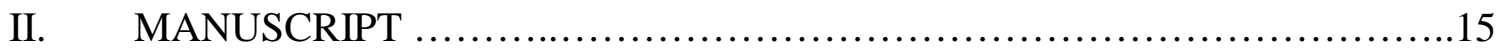

Introduction............................................... 15

Results................................................... 16

Discussion...............................................18

Materials and Methods........................................23

References.................................................33 


\section{LIST OF TABLES}

Table

Page

1. Table of Identified Proteins............................................... 28 


\section{LIST OF FIGURES}

$\begin{array}{lll}\text { Figure } & \text { Page }\end{array}$

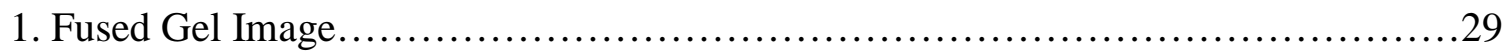

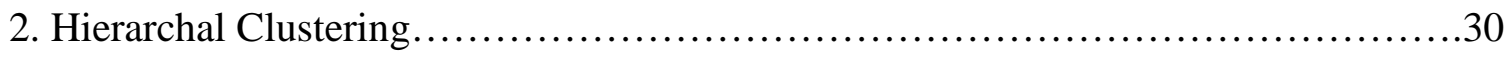

3. Expression Levels.............................................................. 31

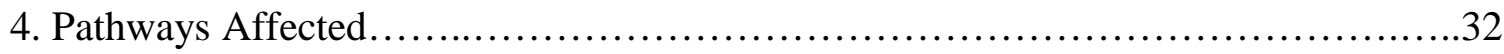




\section{CHAPTER ONE: INTRODUCTION}

Many bays and estuaries around the world are receiving high levels of nitrate through agriculture and wastewater run-off (1). To date, effects of increased levels of nitrate on the physiology of marine organisms have not been thoroughly studied. The Pacific oyster, Crassostrea gigas, is an economically important species frequently farmraised in estuaries that experience nitrate pollution. Using proteomics, we will attempt to discover novel physiological changes, as changes in protein expression, in response to nitrate stress. Knowledge of these changes in protein expression, at a system level, provide us with new hypotheses regarding the physiological effects of increased nitrate concentrations which we can further investigate.

\section{Nitrogen cycle}

Nitrogen gas $\left(\mathrm{N}_{2}\right)$ is the most abundant gas on our planet, making up $78 \%$ of the Earth's atmosphere. Atmospheric nitrogen gas is converted to ammonia $\left(\mathrm{NH}_{3}\right)$, and the protonated form ammonium $\left(\mathrm{NH}_{4}{ }^{+}\right)$, which is incorporated into biological macromolecules (e.g. proteins, RNA and DNA) by bacteria found in soils and living symbiotically with many plants (1). Ammonium is oxidized to nitrite $\left(\mathrm{NO}_{2}{ }^{-}\right)$and nitrate $\left(\mathrm{NO}_{3}{ }^{-}\right)$under aerobic conditions, a process termed nitrification. Under anaerobic conditions, denitrification occurs by converting nitrate to nitrogen gas $\left(\mathrm{N}_{2}\right)$.

The fixation of nitrogen gas contributes to the increased availability of nitrogen in the environment. Under natural conditions, nitrogen fixation is only conducted in two ways: by plants with symbiotic bacteria and by lightning. Alfalfa and soybean bean plants 
are just two species of legume crops that harbor symbiotic nitrogen-fixing bacteria (1). This process increases the amount of accessible nitrogen species in the soil, making more nitrogen available naturally.

Within an ecosystem, nitrification occurs when ammonia is oxidized to nitrate by chemoautotrophic bacteria, ultimately increasing the nitrate concentrations in the environment. Nitrate can be removed from the environment through denitrification. Denitrification by facultative anaerobic bacteria reduces nitrate $\left(\mathrm{NO}_{3}{ }^{-}\right)$to nitrite $\left(\mathrm{NO}_{2}{ }^{-}\right)$, nitric oxide (NO) and nitrous oxide $\left(\mathrm{N}_{2} \mathrm{O}\right)$, eventually returning the nitrogen gas $\left(\mathrm{N}_{2}\right)$ to the atmosphere (2). Nitrate can also be assimilated and removed from the environment by bacteria, plants and algae. Bacteria assimilate nitrate by reducing it to nitrogen gas when ammonia is not present (2) or use nitrate as an energy source by reducing it to either nitrite or ammonia. Although nitrate is the most abundant species of nitrogen in aquatic systems, it is considered the least toxic form of nitrogen when compared to ammonia and nitrite $(3,4)$.

The natural nitrogen cycle, however, is continually being altered by human activities through use of fertilizers and the combustion of fossil fuels. Conversion of nitrogen gas to ammonia is part of a large industry producing fertilizers for agricultural crops (1). Overall, the process of artificial nitrogen fixation removes nitrogen from the air and saturates the soils with ammonia. Ammonia is assimilated by plants, but the unused portions can significantly affect the surrounding environment; eventually undergoing nitrification leading to high nitrate concentrations in soil (5), which may erode or leach into surface or ground waters. Nitrogen in the form of ammonia can also saturate the soil and volatilize into the atmosphere. The accumulation of nitrogen sources often leads to an 
increase in the mobility of nitrogen, affecting the ecosystem level (5). In addition, the combustion of fossil fuels contributes to the increased availability of nitrogen species in aquatic ecosystems. The fixed nitrogen stored in underground deposits can be transferred upon combustion to the atmosphere as nitric oxide (NO) and nitrous oxide $\left(\mathrm{N}_{2} \mathrm{O}\right)(1)$. This increased artificial fixation of nitrogen causes an amplified availability of nitrogen species in many environments. All organic nitrogen species have become more abundant and as a result sensitive ecosystems can be directly affected $(1,5,6)$.

\section{Eutrophication}

High levels of organic nitrogen in aquatic environments, such as rivers, lakes and estuaries, can cause an increase in the primary production, called eutrophication. Eutrophication can induce hypoxic conditions, affecting the ecosystem as a whole (7). Anthropogenic sources contribute to the increasing levels of nitrogen in systems that undergo eutrophication. Organic nitrogen from fertilizers can saturate topsoil and will be released into surface waters in the form of run-off. Examples of such processes are runoff of contaminated surface waters and agriculture, leaching of ground water or septic systems, and accidental sewage spills. Increasing levels of nitrate in a marine system can lead to an increase in the rapid, and in some cases exponential, growth of primary production including algae, phytoplankton and benthic macrophytes (7). Excessive eutrophication can lead to significantly increased biomass, species composition and changes in productivity (7). This drastic increase of phytoplankton and nuisance algal forms increases water turbidity and thereby decreases the light penetration, limiting the growth of microphytobenthos (6). If the contamination is severe enough, the lack of 
sunlight will destroy the photosynthetic organisms at lower depths, creating an anoxic environment, eventually leading to the demise of benthic organisms such as sessile mollusks and shellfish. This process often results in the loss of biodiversity.

\section{Morro Bay}

Estuaries are marine environments characterized by high amounts of primary production. Nitrogen levels have been greatly altered through increasing levels of nutrients, mainly of anthropogenic origin, in many aquatic ecosystems worldwide (6). Morro Bay is a small estuary along the Central Coast of California. It has been shown that inadequate wastewater treatment and septic systems from the town of Los Osos, as well as agricultural run-off, are likely to contribute to the high nitrate levels found periodically throughout the bay (8). According to Los Osos Community Services District (LOCSD) data in November 2006 (9) there are some cases where 6 to 10 septic systems have been established within one acre, many of which are saturating the underground water table with nitrate. Heavy rains in the winter months can influence underground hydrological movement, effectively "washing" the basin surrounding the septic tanks causing septic tank effluent to surface and drain into the estuary contributing to increased levels of nitrate (9). As an example, nitrate concentrations of up to $2.48 \mathrm{mg} \mathrm{NO} / / \mathrm{L}$ have been recorded during a four day time period of a heavy winter storm in 2007 (10). Low levels of nitrate can usually be degraded during denitrification. However, soils in Los Osos and Morro Bay are sandy and contain low abundance of microbial activity. This leads to a slow denitrification rate and nitrate accumulates to very high levels (9). 


\section{Toxicity of nitrate}

Studies on lethal limits have shown that only very high concentrations of nitrate have lethal effects, suggesting that it is not directly toxic to organisms at levels found in the marine environment. Much of the data available is in the form of $\mathrm{LC}_{50}$, the concentration at which the mortality rate reaches $50 \%$. The recorded median $\mathrm{LC}_{50}(96-\mathrm{h})$ for adult and juvenile oysters, Crassostrea virginica, is $11.53 \mathrm{~g} \mathrm{NO}_{3} / \mathrm{L}$ and $16.80 \mathrm{~g} \mathrm{NO}_{3} / \mathrm{L}$, respectively (11). Similarly, the $\mathrm{LC}_{50}$ (72-h) to bay scallops, Argopecten irradians irradians, was calculated to be $19.17 \mathrm{~g} \mathrm{NO}_{3} / \mathrm{L}$ (12). A concentration of $9.92 \mathrm{~g} / \mathrm{L}$ nitrate also contributes to sub-lethal effects including adverse changes in the clearance rate of suspended algae for both adults and juveniles $C$. virginica (11).

It is unlikely that nitrate levels encountered in the oyster's natural habitat will ever be high enough to be considered lethal $(4,12,13)$. Fresh surface waters have been recorded to contain nitrate levels as high as $110 \mathrm{mg} \mathrm{NO}_{3} / \mathrm{L}$, whereas groundwater can found to be much higher at $440 \mathrm{mg} \mathrm{NO} / / \mathrm{L}$ (3). In a recent review on nitrate and its effects on marine organisms, the maximum suggested level of nitrate, for marine animals in general, was estimated to be $88.6 \mathrm{mg} \mathrm{NO}_{3} / \mathrm{L}$ (3). It has also been noted that many marine larval stages are affected more greatly by increased nitrate concentrations.

Marine organisms, when compared to freshwater organisms, seem to have a high tolerance to high concentrations of nitrate, most likely due to the limited uptake of nitrate across respiratory surfaces. Nitrate and nitrite compete with the uptake of chloride ions across the gills surface (13). However, because the extracellular fluid in marine invertebrates is iso-osmotic in regard to chloride ions, it does not require transport that facilitates nitrate uptake (14). 
It is well documented that endogenous and dietary nitrate affects the binding of oxygen to hemoglobin. Nitrate has traditionally been considered toxic primarily due to its conversion to nitrite; possibly by bacteria found in the intestines. Nitrite in the blood generates methemoglobin by oxidizing the iron in hemoglobin to the $\mathrm{Fe}(+3)$ state, resulting in hemoglobin or hemocyanin that inefficiently binds oxygen (15). Because nitrate concentrations in contaminated groundwater are higher than $440 \mathrm{mg} \mathrm{NO} / \mathrm{L}$ in large agricultural areas (16) and amount much smaller than this can cause the formation of methemoglobin in infants, the limit for nitrate concentration in drinking water was set as $44.26 \mathrm{mg} \mathrm{NO} / \mathrm{L}$ (equivalent to $10 \mathrm{mg} \mathrm{NO}_{3}-\mathrm{N} / \mathrm{L}$ ) by the U.S. EPA.

A recent study shows that high endogenous and dietary nitrate can be reduced to nitric oxide in vitro and may be involved in nitric oxide homeostasis in various mammal tissues (17). The enzyme xanthine oxido-reductase catalyzes the reduction of nitrate to nitric oxide (17). The findings of this paper describe the reduction of nitrate to nitric oxide in eukaryotes through endogenous pathways that are independent of bacterial activity under aerobic conditions. A homologous enzyme has been discovered in the mollusk Chlamys farreri, and was found to be produced during an induced infection by a common fish bacteria, Vibro anguillarum (18). We are assuming that this enzyme also exists in C. gigas, although this has not been shown. High amounts of nitrate can be converted to nitric oxide; a signaling molecule that is endogenously produced in Crassostrea and Mytilus (19). High concentrations of nitric oxide can be used by the phagocytes in many mollusks as an innate immune response to destroy invading bacteria and protozoan pathogens (20). It was found that Mytilus galloprovencialis produces nitric oxide that reacts with superoxide anion $\left(\mathrm{O}_{2}^{-*}\right)$ to produce peroxynitrite $\left(\mathrm{ONOO}^{-}\right)$; a strong 
oxidizing agent to kill bacteria (19). At high concentrations, however, peroxynitrite can be extremely harmful by oxidizing DNA, membranes and proteins.

Though the information on the in vivo effects of nitrate is available, the toxic effects of nitrate specifically have not been thoroughly determined in marine organisms. Because of this, little is known about the acute and chronic toxicity of nitrate to marine organisms; particularly on the physiological level. The purpose of this study is to assess the physiological affects of nitrate on a typical marine organism at concentrations of nitrate that have been documented.

\section{Crassostrea gigas}

Pacific oysters (Crassostrea gigas) are raised in estuaries that are characterized by wide variations in environmental conditions, including salinity fluctuations and numerous anthropogenic pollutants. They are a valuable economic species in many parts of the world, including Morro Bay, California where two active oyster farm operations exist. Oysters consume flagellates $(>5 \mu \mathrm{m})$, dinoflagellates, and ciliates at a rate of up to $16.7 \mathrm{~L}$ $\mathrm{h}^{-1} \mathrm{~g}^{-1}$ based on the dry weight of the oyster (21). While they are filtering, they take up and accumulate many of the pollutants that are typically found in estuaries and store them in the hepatopancreas. Because oysters bioaccumulate a number of anthropogenic pollutants, they provide a great study system for assessing ecosystem health (22). Oysters may therefore be an ideal indicator organism. One difficulty, however, are the high genetic polymorphisms recently found in the genome of C.gigas, at a rate of approximately one single nucleotide polymorphism in every forty base pairs (23). As a comparison, the human genome only has one single nucleotide polymorphism in every 1- 
2 kilobases (23). This high genetic variation is likely to cause high levels of protein polymorphisms, which may represent a challenge when comparing protein expression patterns (PEP's). It may also add to the difficulty in sequencing or annotating the genome, and may be one reason the Pacific oyster is not yet considered a model organism. Despite this, there are currently over 29,000 nucleotide sequences available in the form of an Expressed Sequence Tag (EST) library for $C$. gigas, which are available through the publically accessible National Center for Biotechnology Information (NCBI) website.

To assess the feasibility of the project, a trial run experiment during Fall 2006 was conducted using increasing levels of nitrate. During the analysis of these data, it was determined that many differences in protein expression were noticed depending on which individual the protein was extracted from. This was concluded to be caused by individual polymorphisms producing variation in protein expression mentioned above. To account for this variation, all future experiments used the same tissue from each of five oysters in multiple treatments, in effect blocking for individual variation.

\section{Proteomics}

In an average cell, at any given time, there are thousands of proteins with many different functions. The genome and copying of DNA, production of messenger RNA, translation of proteins and post-translational modifications of proteins are all tightly regulated at each step. Classic techniques that use messenger RNA as a quantitative assessment for changes in gene expression may be overlooking many additional signals. As an alternative, the use of proteomics plays a complementary role by observing 
changes in the expression of multiple proteins simultaneously. It can also detect posttranslational modifications that affect the functionality of specific proteins. Because it can be difficult to predict the change in expression for specified proteins in a given treatment, many of the experiments using two-dimensional gel electrophoresis use a discoverydriven approach. Proteomics allows us to observe multiple protein changes and coexpression patterns in a particular tissue as a response to treatment, without biasing the results. Usually after the experiment has been analyzed, specific hypotheses can be proposed regarding the experimental treatment and the proteomic response of the organism.

After conducting the experiment, the proteins must be homogenized in a denaturing buffer with a high concentration of urea $(6 \mathrm{M})$ to solubilize the tissue. By adding a reducing agent, dithiothreitol, we also reduced any disulfide bonds that could interfere with the separation of proteins during electrophoresis. The sample is then centrifuged to remove the proteins and lipids that did not solubilize and it is rehydrated in a fresh buffer containing minimal salts and surfactants. The protein concentration of this solution is then determined and samples are diluted to $2 \mu \mathrm{g} / \mu \mathrm{L}$. The dehydrated $1^{\text {st }}$ dimension strip is rehydrated with $200 \mu \mathrm{L}$ of protein solution. When an electrical current is applied to the rehydrated strip, it causes separation of the proteins based on their isoelectric focusing point ( $\mathrm{pI}$ ). The $\mathrm{pI}$ of the protein is determined based on the composition of the charged amino acids in the protein. Each protein will move toward the cathode (+) or the anode (-) end of the focusing unit until it reaches its pI, the point at which the protein has a neutral charge. 
The proteins must be reduced again before the second dimension using dithioerythritol to ensure the sulfide bonds are reduced. The thin gel strip is placed onto a sodium dodecyl sulfate (SDS) polyacrylamide gel. The SDS adds a negative charge to all regions of the protein evenly to maintain the charge throughout the separation that is proportional to the molecular weight of the protein. An electrical current is applied causing the proteins to move toward the cathode. Larger proteins get trapped in the acrylamide matrix, while smaller proteins avoid this and move faster, separating the proteins in the $2^{\text {nd }}$ dimension by molecular weight.

After staining with colloidal Coomassie Blue, the proteins can be visualized and imaged. Imaged gels are uploaded into the gel image analysis program Delta2D (Decodon) where all the protein expression profiles in the project are warped to one another to ensure suitable alignment (24). The images are then fused into one average gel that represents each individual gel equally. This fused image is used to detect and circle the protein spots, so when the spots are transferred, each gel in the project has the same proteins circled. The quantification of each protein can now be conducted by determining the volume of each protein normalized against the entire protein content in each sample. In experiments with only one treatment, a simple one-way analysis of variance can be used to compare the normalized volumes among groups. For more complicated experiments with multiple factors a two-factor analysis of variance can be used. Additional information about the protein expression can also be examined by graphing the normalized protein expression for each protein and comparing the trends across treatments. Proteins determined as significantly changing in expression in certain treatments can then be identified. 
To identify proteins of interest, the proteins can be removed (in the form of a gel plug) and washed to remove the colloidal Coomassie Blue staining. The gel piece is dehydrated, and then rehydrated with the digestive enzyme trypsin. At $37^{\circ} \mathrm{C}$, trypsin cleaves the peptide bonds at the amino acids arginine and lysine, creating fragments of the original protein. After extraction from the gel, the proteins are mixed with a matrix, assisting volatilization of the peptides while in the mass spectrometer. After plating and washing the peptides to remove any residual salts, the target plate is loaded into the mass spectrometer. A laser in the mass spectrometer is used to ionize the peptide fragments, each of which is detected as a peak at a specific mass versus charge ratio.

This pattern of detected proteins, called a peptide mass fingerprint (PMF), can then be checked against specific Expressed Sequence Tag (EST) libraries to determine a homologous peptide sequence. EST libraries use messenger RNA to create complementary DNA and then undergo forward and reverse sequencing to create the EST library. These libraries effectively contain only the expressed genes formatted as mRNA and contain no introns or non-coding regions. When using this tool for identification purposes, an EST library will provide information in the form of a peptide sequence of amino acids without revealing the identity of the actual protein.

The software program MASCOT searches the EST database assuming that each nucleotide sequence in the database has been lysed with trypsin, cutting the protein at the C-terminal site of arginine and lysine residues, and assigns a score for the protein match. The score is dependent on the total number of proteins in the database and the number of peptides matched. For example, the $C$. gigas database contains 29,000 nucleotide sequences. A matching protein must be assigned a score of 67 of greater to be statistically 
significant $(\alpha-$ level <0.05). Because the scoring technique in MASCOT uses a logarithmic scale, an increase of 10 points is equivalent to an increase in the significance by 100 . After the protein of interest is recognized, the sequence can then be searched using the Basic Local Alignment Search Tool (BLAST) for homologous coding sequences (that are sequenced and annotated) within the entire database to finally determine the protein identification based on homology. The proteins that are usually identifiable using this procedure are conserved across many different species.

Using $C$. gigas, most proteins are not automatically significant with only a PMF. In this case, and for additional confirmation of PMF's, the individual peptides can be fragmented separately through post-source decay (PSD). The fragments can be ionized separately to determine the exact amino acid content/sequence. Tandem mass spectrometry combines the peptide sequences with the original PMF to assess the significance. The significance is scored by summing up the individual peptide scores, which each must be greater than 34 to be statistically significant (representing a $\alpha$-level $<0.05$ ). After tandem mass spectrometry, the scores are usually extremely high (around 300-500) for many proteins. After a protein sequence is found as significant, the sequence must be searched using BLAST, as discussed earlier, to identify the protein by comparing the sequence to a homologous and annotated protein. Using this technique, it is possible to use non-sequenced organisms such as, C.gigas, to identify proteins; however, the number of identified proteins may depend on the size of the EST library used and the amount of sequence homology within other organisms.

\section{Prelude to paper}


The background information included here has covered many aspects of this thesis in detail to understand the procedures and the amount of work that was necessary to complete the manuscript that resulted from this study. Proteomics provides us with an unbiased approach to determining changes in the expression of proteins in response to any given environmental change or stress. It has allowed us to determine multiple proteins that have been regulated in order to combat the stress of increased nitrate concentrations, which we show affects aquatic organisms at a physiological level. To our knowledge, this may be the first paper that acknowledges this.

\section{References}


1. Vitousek PM, et al. (1997) human alteration of the global nitrogen cycle: sources and consequences. Ecological Applications 7:737-750.

2. Jaap van Rijn YT, Schreier HJ (2006) "Denitrification in recirculating systems: Theory and Applications." Aquacultural Engineering 34: 364-376.

3. Camargo JA, Alonso A, \& Salamanca A (2005) Nitrate toxicity to aquatic animals: a review with new data for freshwater invertebrates. (Translated from eng) Chemosphere 58(9):1255-1267 (in eng).

4. Jensen FB (1996) Uptake, elimination and effects of nitrite and nitrate in freshwater crayfish (Astacus astacus). Aquatic Toxicology 34:95-104.

5. Carpenter SR, et al. (1998) Nonpoint pollution of surface waters with phosphorus and nitrogen. Ecological Applications 8:559-568.

6. Camargo JA \& Alonso A (2006) Ecological and toxicological effects of inorganic nitrogen pollution in aquatic ecosystems: A global assessment. (Translated from eng) Environ Int 32(6):831-849 (in eng).

7. Rabalais NN (2002) Nitrogen in aquatic ecosystems. Ambio 31:102-112.

8. Water Quality report, Southern California Water Company, 2005. http://www.aswater.com/CSC/Water_Quality/Water/LSO_A_27_v2.pdf

9. Central Coast water board Los Osos prosecution team. 2006

10. SLOSEA (2007) unpublished data.

11. Epifano CE and Srna RF (1975) Toxicity of ammonia, nitrite ion, nitrate ion, and orthophosphate to Mercenaria mercenaria and Crassostrea virginica. Mar. Biol. 33:241-246.

12. Widman JC, Meseck SL et al. (2008). "Toxicity of un-ionized ammonia, nitrite, and nitrate to juvenile bay scallops, Argopecten irradians irradians." Arch Environ Contam Toxicol 54(3): 460-5.

13. Jensen FB (1996) Uptake, elimination and effects of nitrite and nitrate in freshwater crayfish (Astacus astacus). Aquatic Toxicology 34:95-104.

14. Withers PC (1992) Comparative Animal Physiology (Brooks Cole, Pacific Grove) p 1088.

15. Rodkey LF (1996) A Mechanism for the Conversion of Oxyhemoglobin to Methemoglobin by Nitrite. Clinical Chemistry 22(12):1986-1990.

16. Canter LW (1996) Nitrates in Groundwater. CRC-Press.

17. Jansson EA, et al. (2008) A mammalian functional nitrate reductase that regulates nitrite and nitric oxide homeostasis. (Translated from eng) Nat Chem Biol 4(7):411-417 (in eng).

18. Song L, Xu W, Wang H, Li H (2005) Chlamys farreri submission to EST library. Unpublished data.

19. Torreilles J and Romestand R (2001) In vitro production of peroxy nitrite by haemocytes from marine bivalves: C-ELISA determination of 3-nitrotyrosine level in plasma proteins from Mytilus galloprovencialis and Crassostrea gigas. BMC Immunology. Aquat. Living Resour. 13: 173-177

20. Villamil L, Gomez-Leon J, Gomez-Chiarri M (2007) Role of nitric oxide in the defenses of Crassostrea virginica to experimental infection with the protozoan parasite Perkinsus marinus. Developmental and comparative Immunology 31:968-977.

21. Dupuy C, et al. (2000) Feeding rate of the oyster Crassostrea gigas in a natural planktonic community of the Mediterranean Thau Lagoon. Marine Ecology Press Series 205:171-184.

22. Wootton EC, Dyrynda EA, Pipe RK, Ratcliffe NA (2003) Comparisons of PAH-induced immunomodulation in three bivalve mollusks. Aquatic Toxicology 65:13-25.

23. Wharam SD, Wardill TJ, Goddard V, Donald KM, Parry HP, Pascoe P (2008) A leucine aminopeptidase gene of the Pacific oyster Crassostrea gigas exhibits an unusually high level of sequence variation, predicted to affect structure, and hence activity, of the enzyme. Journal of Shellfish Research 27 (5): 1143-1154

24. Berth M, Moser FM, Kolbe M, Bernhardt J (2007) The state of the art in the analysis of twodimensional gel electrophoresis images. Applied Microbiology and Biotechnology 76 (6): 12231243.

\section{CHAPTER TWO: MANUSCRIPT}




\section{Introduction}

Nitrate $\left(\mathrm{NO}_{3}{ }^{-}\right)$is one of the most common ionic forms of nitrogen in aquatic ecosystems (1). The various nitrogen species enter ecosystems through natural processes, e.g. atmospherichydro-geological depositions and biological degradation of organic material, as well as through anthropogenic inputs, e.g. fertilizers, manure and sewage effluents. Human activity has greatly altered the global nitrogen cycle, making nitrogen more available to aquatic communities, with eutrophication, hypoxia and loss of biodiversity being the most common effects on the ecosystem level (2-4). However, nitrate is considered less toxic to individual organisms than the other less common ionic forms of nitrogen $(5,6)$.

The low permeability of nitrate across respiratory surfaces of aquatic organisms in comparison to ammonium and nitrite decreases the likelihood of toxic effects (5, 7-9). Furthermore, the permeability seems to depend in part on the chloride gradient between the aquatic environment and the organism, increasing as nitrate and nitrite compete with the chloride up-take mechanisms that are typical for freshwater organisms (5). The net transport of chloride is reversed for marine teleosts that are hypoosmotic, reducing the permeability of nitrate. In the case of marine invertebrates, the extracellular fluid is isosmotic to seawater in regard to chloride ions (10) eliminating any chloride transport that could facilitate nitrate uptake, making it even less likely that it will exert an important physiological stress. However, it is known that high levels of nitrate can form chemical species, e.g. methemoglobin, that prevent oxygen from binding to hemoglobin and hemocyanin and thus interfere with the transport of oxygen in marine organisms $(5,8,11)$.

Despite these various reasons that argue for a low toxicity of nitrate in aquatic, specifically marine organisms, there is recent evidence that suggests that nitrate may exert physiological effects through the formation of other nitrogen species, specifically nitric oxide 
(12). In mammals nitrate can be reduced to nitrite and nitric oxide, indicating that it may play a role in the metabolism of nitric oxide and its signaling effects (12). Although common in prokaryotes, such nitrate reductase activity, specifically under aerobic conditions, is a novel pathway for eukaryotes (12). At higher levels nitric oxide and superoxide anion radicals $\left(\mathrm{O}_{2} \bullet^{-}\right)$ form peroxynitrite $\left(\mathrm{ONOO}^{-}\right)$, a very aggressive nitrogen species that attacks proteins and nucleic acids (13). Thus, we hypothesized that nitrate, if it is reduced to nitrite and nitric oxide, can indeed exert physiological effects, possibly through the formation of reactive nitrogen species (RNS).

To address the paucity of our knowledge on the physiological effects of nitrate from a less biased perspective, we applied a proteomics approach to assess changes in protein expression as a means to discover novel cellular effects of acute nitrate exposure. We used the Pacific oyster, Crassostrea gigas, for our study because it is commonly farmed in estuaries where nitrate levels can be highly elevated for a short period of time due to agricultural run-off and sewage discharge (4). In addition, $C$. gigas is an emerging model organism with an increasing number of identified gene sequences and expressed sequence tags, augmenting the identification of proteins using mass spectrometry (14).

\section{Results}

\section{Proteome map}

The 2D gel image in Figure 1 shows the proteome map of gill tissue samples of the Pacific oyster, $C$. gigas, exposed to nitrate concentrations ranging from $0-73 \mathrm{mg} \mathrm{NO} / \mathrm{L}$. The proteome map is a pooled image that represents average pixel volumes (expression levels). Careful examination of spot boundaries revealed a minimum of 642 detectable protein spots within the range of $\mathrm{pH} 4-7$.

\section{Proteins of interest}


Proteins that changed expression levels (two-factor ANOVA; $\alpha<0.05$ ) and were identified are labeled on the proteome map (Fig. 1) and grouped under their putative protein function (Tab. 1). Fifteen of 24 proteins were identified by searching peptide mass fingerprints and tandem mass spectra of protein spots against an expressed sequence tag library that was downloaded from the taxonomy browser of the NCBI database. A minimum of two peptide matches was required for the positive identification of a protein, but most proteins had three or more peptides that matched and very high molecular weight search (MOWSE) scores (Tab. 1).

The proteins that changed expression are involved in the regulation of cellular redox balance (thioredoxin and cavortin), G-protein signaling (two Rho-guanine dissociation inhibitor proteins or Rho-GDI, ADP ribosylation factor or ARF, and the beta-subunit of a trimeric Gprotein), protein homeostasis (Hsp70, calreticulin, prohibitin and proteasome $\alpha$-subunit) and structuring of the cytoskeletal network (intermediate filament and adseverin). Enolase is the single glycolytic protein that was found to change expression. Lipocalin is a small extracellular protein that plays a role in the transport of hydrophobic molecules (15). One protein is

homologous to the UPF protein superfamily, whose members are involved in nonsense-mediated RNA decay in humans (16).

\section{Quantification of protein expression}

We analyzed 2D gel images quantitatively using Delta2D. We applied hierarchical clustering to the quantified expression data of the identified proteins and obtained two main clusters: one cluster of 5 proteins, which were up-regulated at lower nitrate levels and another with 19 proteins, all of which were first down-regulated at lower and then up-regulated at higher nitrate concentrations relative to the control (Figs 2 and 3). We identified 2 proteins (cavortin and an intermediate filament protein) in the first cluster whose expression is distinct from the 13 identified proteins in the second cluster. Both clusters show non-linear expression patterns with 
increasing nitrate concentration (Fig. 3). Overall, the response to nitrate seems to be most different between the lowest ( $18 \mathrm{mg} \mathrm{NO}_{3} / \mathrm{L}$ ) and the highest $\left(73 \mathrm{mg} \mathrm{NO}_{3} / \mathrm{L}\right)$ nitrate treatment concentrations (Tukey post-hoc analysis, $\alpha<0.05$ ); however, expression levels at higher concentrations of nitrate are often not statistically different from the control.

\section{Discussion}

The changes in protein expression patterns we found in gill tissue of the Pacific oyster $(C$. gigas) are an indication that nitrate can exert physiological stress in aquatic organisms beyond the inhibition of oxygen binding to hemoglobin and hemocyanin $(5,6)$. This physiological stress may be caused by the reduction of nitrate to nitrite and further to nitric oxide, a process requiring nitrate reductase activity, which is common in bacteria but has not been shown to exist in eukaryotes until recently (12). High levels of nitrate can be converted to nitric oxide by xanthine oxidoreductase, an enzyme that catalyzes the conversion of purines to uric acid (12); although we have not found a xanthine oxidoreductase sequence in the publically accessible expressed sequence tags for Crassostrea, a sequence homologous to xanthine oxidoreductase has been described for the scallop Chlamys farreri (GI 115426931). At higher levels NO can react with superoxide anion radicals $\left(\mathrm{O}_{2} \bullet\right)$ to form peroxynitrite $\left(\mathrm{ONOO}^{-}\right)$, which is a potent reactive nitrogen species with anti-bacterial and anti-protozoan activity in oysters as well as the potential for denaturing proteins (17-20). High levels of nitric oxide have been shown to either directly, or through peroxynitrite, act as an important intracellular signal during the defense against invading microorganisms (13), a strong oxidant of thiols $(21,22)$, and a promotor of tyrosine nitration (23) and S-nitrosylation of proteins (24). We propose that the changes in protein expression in our study are a response to the formation of reactive oxygen species (ROS) and reactive nitrogen species (RNS; Fig. 4). 
The first sign for an important role of oxidative stress in the response of $C$. gigas to nitrate was the increased expression of thioredoxin (Fig. 3), an enzyme that plays an important role in the regulation of the redox balance of the cell (25). However, the next evidence at first appeared paradoxical: While thioredoxin first decreased but then increased in response to increasing levels of nitrate, cavortin (an abundant hemolymph protein in oysters and a member of the superoxide dismutase (SOD) protein family)(26) first increased and then decreased in response to increasing nitrate levels (Fig. 3). SOD activity scavenges $\mathrm{O}_{2} \bullet \bullet$ and thus has the potential to alleviate peroxynitrite formation despite increasing levels of nitric oxide $(21,23)$. However, SOD isoforms also catalyze the S-nitrosylation of proteins, interfering with their functionality, while thioredoxin works in the opposite direction, de-nitrosylating proteins (24). Thus, we hypothesize that at low levels of nitrate exposure, cavortin may be up-regulated to control the formation of peroxynitrite. At high levels of nitrate exposure, cavortin is downregulated while thioredoxin is up-regulated to limit SOD activity and prevent harmful levels of Snitrosylation (Fig. 4).

Oxidative and nitrosative stress have both been shown to cause protein damage through tyrosine nitration and S-nitrosylation, especially when nitric oxide reacts with $\mathrm{O}_{2}{ }^{-} \bullet$ forming peroxynitrite $(23,24)$. The cytotoxic effects of such protein denaturing conditions can be controlled in part through the increased expression of members of the ubiquitin-proteasome system, e.g. proteasome (Fig. 3), and molecular chaperones, e.g. protein-disulfide isomerases (related to thioredoxin), calreticulin and heat-shock proteins (Fig. 3, 27, 28). Thus, the upregulation of several molecular chaperones provides additional evidence for oxidative stress, given that other stresses were absent (Fig. 4).

The knockdown of prohibitin, a member of a chaperone-like protein complex in the mitochondrial membrane (29) has been shown to activate redox sensitive pathways, including one leading from peroxynitrite through phosphatidyl-inositol 3 kinase (PI3K) and protein kinase B 
(PKB or Akt) to Rac1 (a small G-protein of the Rho-family)(30). This pathway leads to modifications of the cytoskeleton (30). Prohibitin was significantly higher expressed at $73 \mathrm{mg}$ $\mathrm{NO}_{3} / \mathrm{L}$ in comparison to $18 \mathrm{mg} \mathrm{NO} / \mathrm{L}$ nitrate (Fig. 3), possibly down-regulating the PI3K/Akt/Rac1 pathway at higher levels of nitrate, as would the observed changes in protein expression of lipocalin and Rho-GDI (Fig. 4).

Lipocalin is the one protein we were not able to directly place into a potential network of pathways that are connected by peroxynitrite and its effects on cells and proteins. However, at least two studies link lipocalin to the PI3K/Akt pathway and show that its up-regulation inhibits the activation of this signaling process $(31,32)$, suggesting that it acts in parallel to prohibitin (Fig. 4). Furthermore, members of the lipocalin protein superfamily, called nitrophorins, are known to sequester nitric oxide (33), a function that may be shared with other members of this superfamily.

The up-regulation of both Rho-GDI isoforms may indicate that nitrate modifies another redox pathway, one that may be down-regulated in response to oxidative stress. Rho-GDI has been found to bind to the membrane anchor of a small G-protein, presumably a member of the Rho-family (from Ras homology), and thereby stabilizes the inactive GDP-bound form and prevents it from entering the cell membrane (34). One of the Rho-family members in mammals is Rac1 (several Rho-family members that are not further specified can be found for Crassostrea in NCBI). In its GTP-bound state, Rac1 alone can activate the assembly of NADPH oxidase, a multienzyme complex that contributes to cellular defense processes $(35,36)$. Phagocytic hemocytes kill invading pathogens by activating NADPH oxidase to reduce molecular oxygen to toxic ROS, in part through an associated mangenese superoxide dismutase (MnSOD) (34, 37-39). We hypothesize that when Rho-GDI is up-regulated in oyster gill tissue the activation of NAPH oxidase is prevented because the Rho-GDI holds a Rac1-homolog in the GDP-bound form. If $C$. gigas generates ROS to fend off invading microorganisms, then the observed down-regulation of 
cavortin (SOD) coupled with the observed up-regulation of Rho-GDI would decrease the cell's defense abilities (Fig. 4). A possible redundant pathway is suggested by the observation that peroxynitrite can inhibit MnSOD directly through tyrosine nitrosylation $(13,40)$.

Although ADP-ribosylation factor (ARF) is mainly known for its role in assembling a membrane-bound multi-protein complex that is necessary for vesicle formation (41), it may catalyze the ADP-ribosylation of Rho-family members (e.g. Rac1), which has been shown to interfere with the recognition of effector proteins downstream (42). Thus, an increase in ARF may have the same effect as an increase in Rho-GDI, mainly to inhibit the activation of ROS through NADPH oxidase and the SOD activity of cavortin.

More support for the presence of oxidative stress in C.gigas due to nitrate exposure comes from another proteomic study on the occurrence of thiol oxidation in response to the prooxidant chemical menadione in the bivalve Mytilus edulis (43). Proteins that form oxidized thiols are thought to scavenge ROS and thereby prevent oxidative stress to other cellular structures. In M. edulis oxidized thiol groups were present in calreticulin, enolase, gelsolin (related to adseverin), protein disulphide isomerase (a member of the thioredoxin superfamily), and RhoGDI. The corresponding proteins that we identified in $C$. gigas were all up-regulated in response to nitrate exposure (Fig. 3). Six out of fifteen proteins changing expression in response to nitrate in C. gigas were identified as forming oxidized thiol groups in Mytilus in response to the prooxidant menadione (43), suggesting that changes in expression levels of these proteins may be a means to scavenge ROS or RNS.

ARF isoforms are also involved in regulating phagocytosis, modifying the cytoskeleton and forming cellular stress fibers by modulating Rac1 activity $(41,44)$. Inhibition of Rac1 by ARF and Rho-GDI, as discussed above, may therefore explain the observed down-regulation of intermediate filaments, as part of modifying the cytoskeleton or forming stress fibers. Adseverin, 
which shares a high degree of homology with gelsolin (45), may also be an effector protein of Rac1 (46), but its expression patterns in response to nitrate were opposite to the ones of the intermediate filament protein (Fig. 3).

Hemocytes defend bivalves from microorganisms through phagocytosis and the production of ROS to kill the invading pathogens, most likely through the activation of NADPH oxidase $(18,47)$, although it is unclear how active this pathway is in Pacific oysters (48). The high levels of phagocytic hemocytes in gill tissues of oysters and the high abundance of cavortin, an extracellular hemocyte protein, in our gels (several additional spots were also identified as cavortin, data not shown) supports this defense strategy (26). Assuming that hemocytes are abundant in oyster gill tissue the following possible scenario emerges from our data: increasing levels of nitrate form nitric oxide, which reacts with $\mathrm{O}_{2} \cdot \bullet$, a process that outcompetes the scavenging activity of cavortin (38), forming harmful levels of peroxynitrite. At the same time, the generation of ROS by NADPH oxidase as part of the phagocytic and anti-bacterial activity of hemocytes is down-regulated. Thus, we hypothesize that oxidative stress caused by nitrate inhibits the production of ROS in phagocytic hemocytes in gill tissue, possibly affecting the immune competency of hemocytes.

Interestingly, several of the genes we identified as changing in response to nitrate exposure show opposite trends in Eastern (C. virginica) and Pacific (C. gigas) oysters challenged with a parasite infection (49). It is unclear if this hypothesized down-regulation of the immune response that is based on the production of ROS and RNS (20) affects the immune response of oysters to pathogens.

The non-linear response to nitrate in almost all of the protein expression profiles suggests that other factors than the formation of RNS may determine the cellular response in the range between $0-18 \mathrm{mg} \mathrm{NO}_{3} / \mathrm{L}$ nitrate. At this point we can only acknowledge the fact and stress 
the need for further exposure experimentation to investigate the proteome response to nitrate within this lower range of concentrations.

An alternate possibility than the one we have presented here is that bacteria residing in the oyster gill tissue reduced nitrate to nitric oxide (50). We cannot completely exclude this possibility. However, none of our protein identifications ever showed a close match with a prokaryotic sequence, suggesting that the quantitative contribution of bacteria to the observed changes in response to nitrate may be limited.

In summary, the changes in protein expression observed in gill tissue of the Pacific oyster, $C$. gigas, in response to nitrate provide evidence for an oxidative stress response, most likely due to the increasing production of peroxynitrite via the reaction of nitric oxide and $\mathrm{O}_{2} \bullet$. Acute nitrate exposure, at least at the levels we used in this study, poses a physiological stress. Consequently, it seems possible that oysters experiencing chronic exposure to nitrate, as is the case in many of our coastal waters, are exposed to elevated levels of oxidative stress, potentially compromising the oysters' immune response and thus contributing to the increased occurrence of summer mortality in oysters across the Northern Hemisphere (51).

\section{Materials and Methods}

\section{Collection and maintenance of animals}

Oysters were collected from an oyster farm operation in Morro Bay, California $\left(35^{\circ} 20^{\prime} 07^{\prime \prime} \mathrm{N} 120^{\circ} 50^{\prime} 44^{\prime \prime} \mathrm{W}\right)$. They were immediately transported to holding aquaria with filtered re-circulating seawater maintained at $13^{\circ} \mathrm{C}$ for at least two weeks before experimentation. They were fed a phytoplankton mixture (DT's Plankton Farm) every two days. We stopped feeding $48 \mathrm{~h}$ before experimentation. 


\section{Experimental conditions}

To control for variation in protein expression among individual C. gigas, gill tissue of individual animals was dissected longitudinally into four pieces and each piece was exposed to one of four sodium-nitrate concentrations: $0,25,50$ or $100 \mathrm{mg} \mathrm{NaNO}_{3} / \mathrm{L}$, resulting in $0,18,36$ or $73 \mathrm{mg} \mathrm{NO} / \mathrm{L}$ (equivalent to $0,4,8$, and $17 \mathrm{mg} \mathrm{NO}_{3}-\mathrm{N} / \mathrm{L}$ or $0,294,588$ and $1176 \mu \mathrm{M} \mathrm{NO}_{3}$ ) for 6 $\mathrm{h}$ under frequent aeration (15 min intervals) and constant temperature $\left(13^{\circ} \mathrm{C}\right)$. This design accounted for potential individual variation in protein expression using a Random Complete Block Design. We chose a range of nitrate concentrations that encompass observed levels and are considered high for surface waters $\left(18 \mathrm{mg} \mathrm{NO}_{3} / \mathrm{L}\right)$ and ground water(73 $\left.\mathrm{mg} \mathrm{NO} / \mathrm{L}, 3\right)$. The 6hour duration of exposure mimics frequently occurring acute exposures to high levels of nitrate, such as sewage discharges.

\section{Sample preparation}

Immediately following experimentation, tissue samples were minced and homogenized in ice-cold glass homogenizers containing $7 \mathrm{M}$ urea, $2 \mathrm{M}$ thiourea, $40 \mathrm{mM}$ Tris- $\mathrm{HCl}, 1 \% \mathrm{ABS}, 0.5 \%$ IPG buffer, and $200 \mathrm{mM}$ tributylphosphine. Urea is a potent chaotrope and no signs of proteolytic activity were detected. The homogenate was kept at room temperature for $30 \mathrm{~min}$ to dissolve more proteins and was subsequently centrifuged at 15,000 $\mathrm{g}$ for $30 \mathrm{~min}$. The supernatant was precipitated with ice-cold $10 \%$ trichloroacetic acid in acetone for at least three hours at $20^{\circ} \mathrm{C}$, washed with ice-cold $100 \%$ acetone and centrifuged at $15,000 \mathrm{~g}$ for $30 \mathrm{~min}$ at $4^{\circ} \mathrm{C}$. The resulting pellet was quickly dried and dissolved in rehydration buffer (7 M urea, $2 \mathrm{M}$ thiourea, 2\% CHAPS, $2 \%$ NP-40, $0.002 \%$ bromophenol blue, $0.5 \%$ immobilized $\mathrm{pH}$ gradient or IPG buffer, $100 \mathrm{mM}$ dithioerythritol or DTT) overnight at $4^{\circ} \mathrm{C}$. Samples were kept at $-80^{\circ} \mathrm{C}$ until used for further analysis. Protein concentrations were determined using the 2D Quant kit (GE Healthcare) according to the manufacturer's instructions. 
Two-dimensional gel electrophoresis

Proteins were first separated according to their isoelectric point by loading $400 \mu \mathrm{g}$ of protein on a $11 \mathrm{~cm}$ long immobilized pH gradient (IPG) gel strip ( $\mathrm{pH} 4-7$; BioRad; Hercules) for a minimum of $12 \mathrm{~h}$. Rehydrated gel strips were run on an IPGphor 3 (GE Healthcare) isoelectric focusing system under the following running conditions: $500 \mathrm{~V}$ (step, $1 \mathrm{~h}$ ). $1000 \mathrm{~V}$ (gradient, 1 h), $6000 \mathrm{~V}$ (gradient, $2.5 \mathrm{~h}$ ) and $6000 \mathrm{~V}$ (step, $1.5 \mathrm{~h}$ ). Gel strips were subsequently frozen at $80^{\circ} \mathrm{C}$.

Proteins that were separated along the $\mathrm{pH}$ gradient ( $\mathrm{pH} 4-7)$ were then separated by their molecular weight, using sodium-dodecyl-sulfate (SDS) gel electrophoresis. IPG strips were partially thawed and incubated with SDS-equilibration buffer (6 M urea, $50 \mathrm{mM}$ Tris- $\mathrm{HCl}, \mathrm{pH}$ 8.8; $30 \%$ glycerol, $2 \%$ SDS, $0.002 \%$ bromophenol blue) for 15 min each, first with $100 \mathrm{mM}$ DTT and, second, with $250 \mathrm{mM}$ iodoacetamide. IPG strips were placed on top of a $12.5 \%$ polyacrylamide gel with a $0.8 \%$ agarose containing Laemmli SDS electrophoresis buffer $(25 \mathrm{mM}$ Tris-base, $192 \mathrm{mM}$ glycine, 0.1\% SDS). Gels were run (SE 600 Ruby; GE Healthcare) at $15 \mathrm{~mA}$ per gel for the first $15 \mathrm{~min}$ and at $30 \mathrm{~mA}$ per gel for an additional $3.5 \mathrm{~h}$ at $10^{\circ} \mathrm{C}$. Gels were subsequently stained with Colloidal Coomassie Blue (G-250) overnight and destained by washing repeatedly with Milli-Q water for $48 \mathrm{~h}$. The resulting gels were imaged by scanning using an Epson 1280 transparency scanner.

\section{Gel image analysis}

Digitized two-dimensional gel images were analyzed using Delta2D (version 3.6, Decodon, 52, 53). We used the group warping strategy to connect gel images through match vectors. All images were fused to a composite image or proteome map, which represents average volumes for each spot. Spot boundaries were detected within the proteome map and transferred 
back to all gel images using match vectors. After background subtraction, protein spot volumes were normalized against total spot volume of all proteins in a gel image.

Mass spectrometry

Proteins that changed expression levels with treatment were excised from gels using a tissue puncher (Beecher Instruments). Gel plugs were destained twice with $25 \mathrm{mM}$ ammonium bicarbonate in $50 \%$ acetonitrile, dehydrated with $100 \%$ acetonitrile and digested with trypsin (Promega) overnight at $37^{\circ} \mathrm{C}$ at a concentration of $11 \mu \mathrm{g} / \mu \mathrm{l}$. Digested proteins were extracted using analyte solution ( $0.1 \%$ trifluoroacetic acid (TFA)/acetonitrile; $2: 1)$, concentrated using a SpeedVac (Eppendorf)) and rehydrated with $1 \mu \mathrm{l}$ of analyte solution. The analyte solution was mixed with $5 \mu$ of matrix solution $(0.2 \mathrm{mg} / \mathrm{ml} \alpha$-hydroxycyano cinnamic acid in acetonitrile $)$ and spotted on an Anchorchip ${ }^{\mathrm{TM}}$ target plate (Bruker Daltonics), washed with 0.1\% TFA and recrystalized using an acetone/ethanol/0.1\% TFA (6:3:1) mixture.

Peptide mass fingerprints (PMFs) were obtained on a matrix-assisted laser desorption ionization (MALDI) mass spectrometer (Ultraflex II; Bruker Daltonics). Tandem mass spectrometery was conducted on a minimum of six peptides in order to obtain information about the $b$ - and $y$-ions of the peptide sequence. PMFs and tandem mass spectra were combined in a search against an expressed sequence tag library that was constructed from the NCBI taxonomy browser (January 2009), using Mascot as our search engine. We required a minimum of two matched peptides to positively identify a protein spot and obtained MOWSE scores for all proteins above 100, a number considered reliable for protein identification (54).

Statistical analysis

Normalized spot volumes were analyzed using a two-factor analysis of variance (ANOVA), with individual and treatment as variables. Hierarchical clustering was conducted 
within the statistical tool suite within Delta2D. A null distribution was generated using 1000 permutations and a $\alpha$-level of 0.05 was used as the upper limit, although the majority of significant spots showed $\alpha$-levels well below that threshold. Post-hoc testing to compare treatments among each other was conducted using Tukey's analysis $(\alpha<0.05)$. 


\section{TABLE}

Table 1: Proteins identified using tandem mass spectrometry. We compared peptide mass fingerprints and tandem mass spectra against an expressed sequence tag library specific to Crassostrea that we obtained from the NCBI taxonomy browser. All protein MOWSE scores were significant with a minimum of at least two peptides (using tandem MS/MS) matching.

\begin{tabular}{|c|c|c|c|c|c|c|c|}
\hline \multicolumn{8}{|c|}{ Identified Proteins } \\
\hline Spot & Protein ID & $\begin{array}{l}\text { GenBank } \\
\text { EST ID }\end{array}$ & $\begin{array}{l}\text { MOWSE } \\
\text { Score }\end{array}$ & $\begin{array}{l}\text { Peptide } \\
\text { Matches }\end{array}$ & $\begin{array}{l}\text { Sequence } \\
\text { Coverage }\end{array}$ & $\begin{array}{c}\text { NCBI } \\
\text { Homology }\end{array}$ & $\begin{array}{l}\text { NCBI } \\
\text { Score }\end{array}$ \\
\hline \multicolumn{8}{|c|}{ Redox Regulating } \\
\hline 266 & Thioredoxin & gi|164569127 & 253 & 5 & $22 \%$ & gi|14906096 & 126 \\
\hline 463 & Cavortin & gi|189408389 & 317 & 3 & $20 \%$ & gi|48476113 & 353 \\
\hline \multicolumn{8}{|c|}{ G-Protein Signaling } \\
\hline 243 & Rho-GDI & gi|22597951 & 277 & 6 & $40 \%$ & gi|33337635 & 231 \\
\hline 234 & Rho-GDI & gi|22597951 & 236 & 5 & $22 \%$ & $\mathrm{gb} \mid \mathrm{AAQ} 13468.1$ & 151 \\
\hline 374 & $\begin{array}{l}\text { ADP Ribosylation } \\
\text { Factor }\end{array}$ & gi|164571519 & 301 & 5 & $27 \%$ & gi|149054474 & 318 \\
\hline 179 & G-Protein $(\beta)$ & gi|189406824 & 174 & 2 & $8 \%$ & gi|46391574 & 553 \\
\hline \multicolumn{8}{|c|}{ Chaperone-Like } \\
\hline 80 & HSP 70 & gi|189407661 & 140 & 3 & $14 \%$ & gi|4838561 & 499 \\
\hline 407 & Prohibitin & gi|164582452 & 419 & 7 & $45 \%$ & gi|219411329 & 272 \\
\hline 356 & Calreticulin & gi|189408389 & 204 & 3 & $62 \%$ & gi|148717307 & 207 \\
\hline \multicolumn{8}{|c|}{ Cytoskeletal } \\
\hline 14 & Intermediate & gi|152818550 & 186 & 3 & $17 \%$ & gi|48476113 & 353 \\
\hline 116 & Adseverin & gi|22598283 & 161 & 4 & $21 \%$ & gi|40643012 & 299 \\
\hline \multicolumn{8}{|c|}{ Other Groups } \\
\hline 265 & Lipocalin & gi|22598085 & 390 & 4 & $37 \%$ & gi|209730868 & 87 \\
\hline 420 & Proteasome $\alpha-4$ & gi|164569838 & 379 & 8 & $44 \%$ & gi|47550827 & 407 \\
\hline 460 & UPF Suprefamily & gi|168496425 & 177 & 2 & $15 \%$ & gi|50540020 & 106 \\
\hline 302 & Enolase & gi|164577170 & 136 & 2 & $6 \%$ & gi|120972530 & 421 \\
\hline
\end{tabular}




\section{FIGURES}

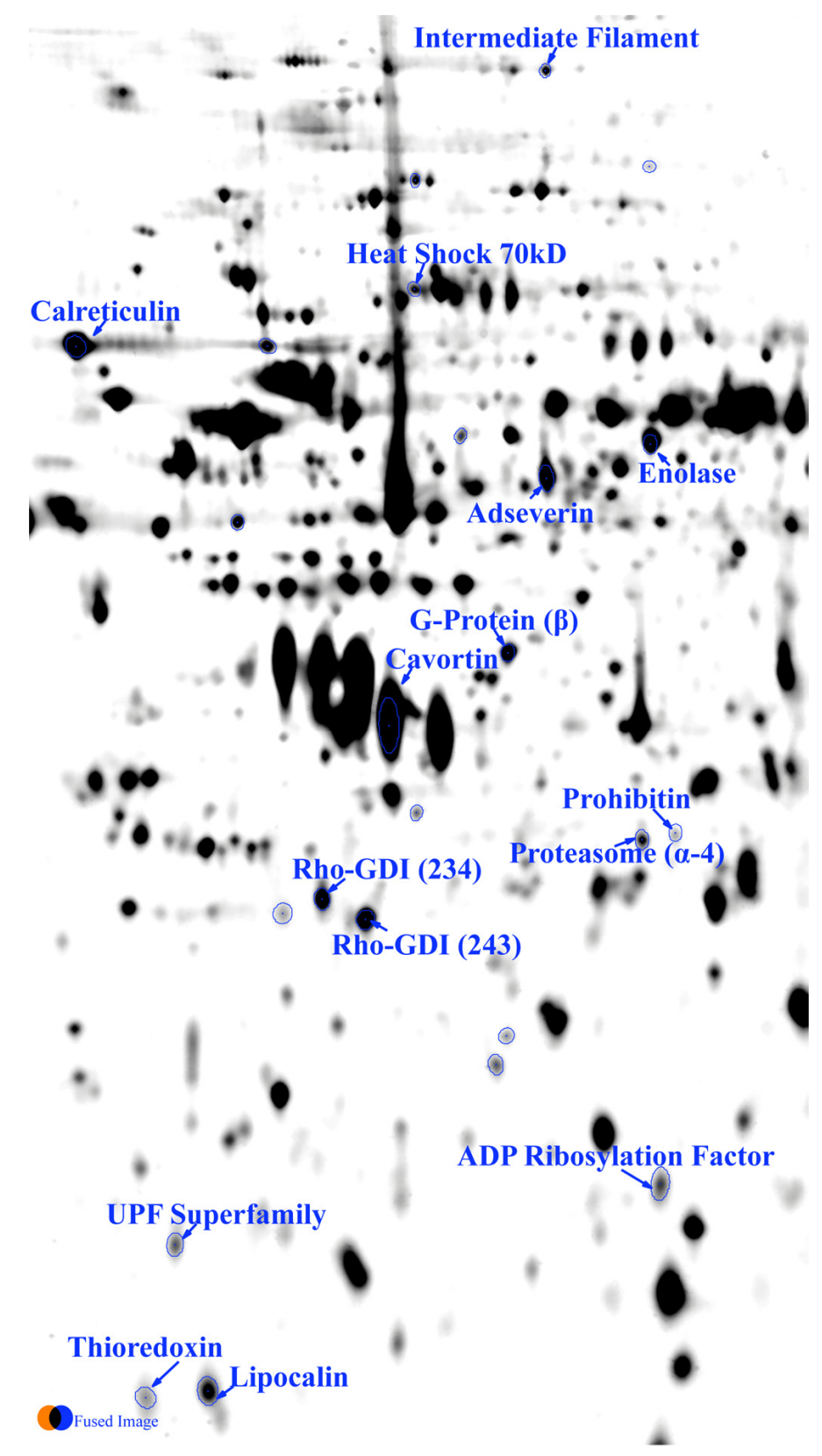

Figure 1: A composite gel image (proteome map) representing protein spots from gill tissue of the Pacific oyster (C. gigas) from all gels in the experiment $(\mathrm{n}=20)$. The proteome map represents average pixel volumes for each protein spot. Circled spots are differentially expressed among treatments with nitrate $(\alpha$-level <0.05). Proteins identified using tandem mass spectrometry are labeled accordingly. 


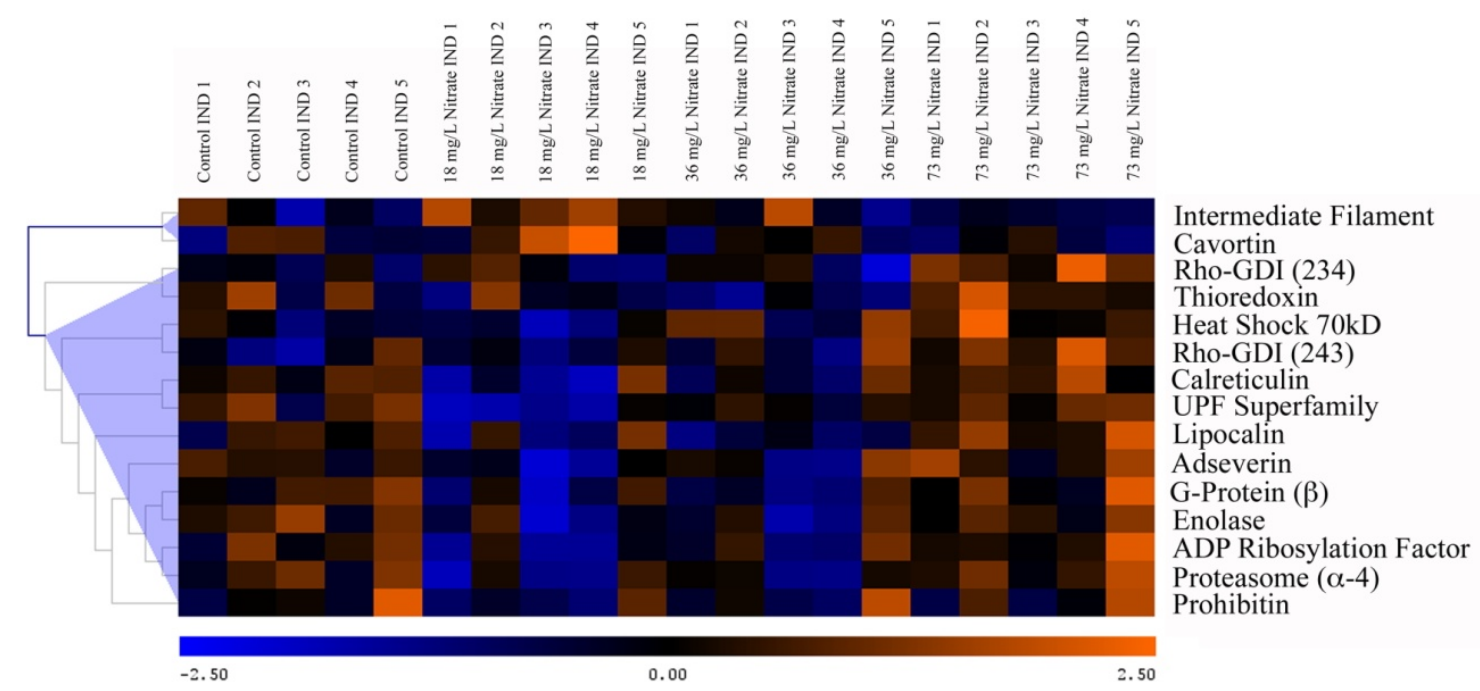

Figure 2: Hierarchal clustering of identified proteins ( 15 of 24 protein spots that are changing expression) using Pearson's correlation. Blue coloring represents a lower than average standardized volume, whereas orange represents greater than average standardized volume. The horizontal axis shows the different nitrate treatment regimes. The vertical axis represents the standardized expression patterns of the identified proteins. The clustering shows two main groups that show opposite patterns of expression. 

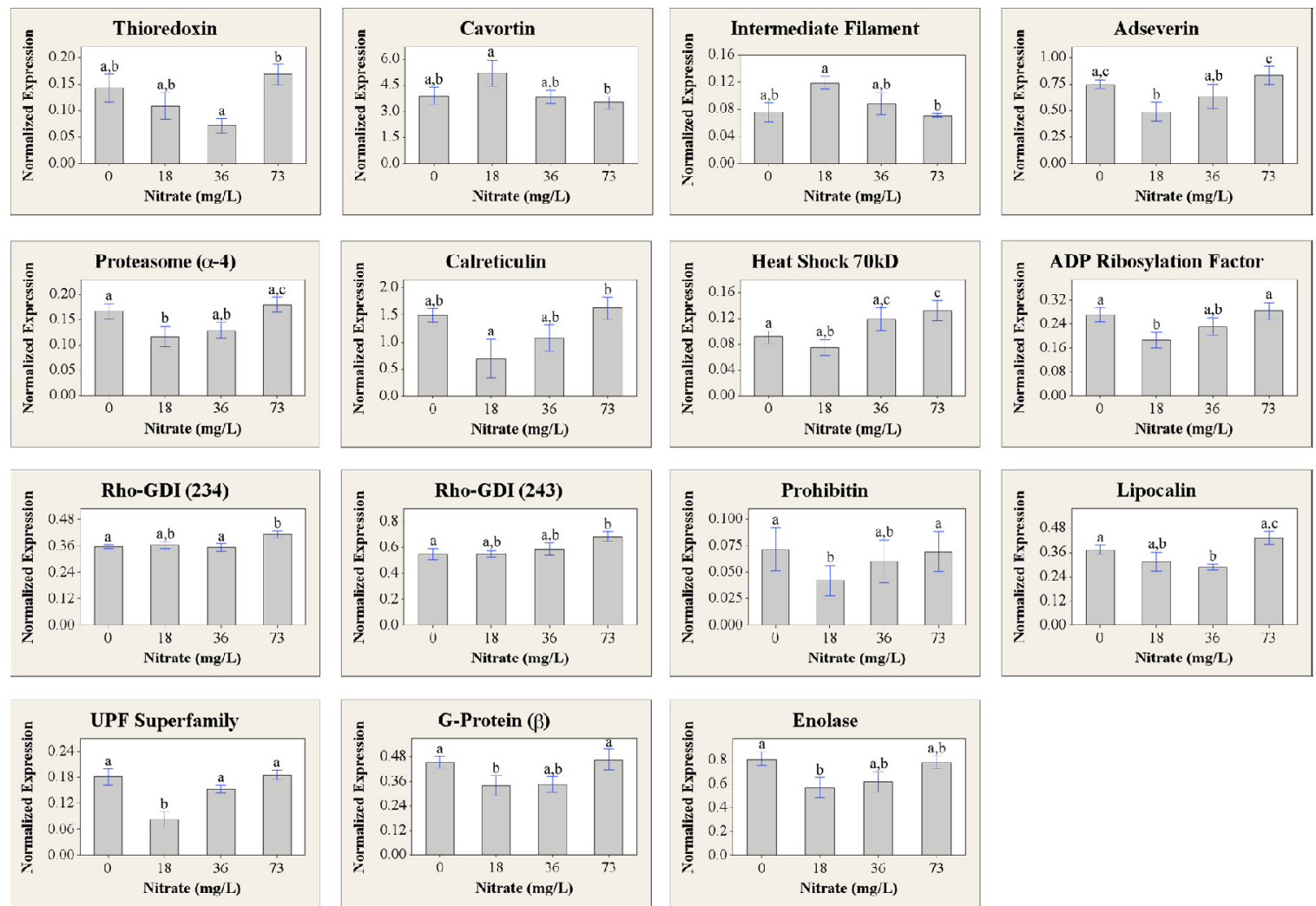

Figure 3: Expression levels of identified proteins differentially expressed in the gill tissue of

Crassostrae gigas in response to nitrate treatment ( $\alpha<0.05 ; \mathrm{n}=5$ for each treatment). Error bars indicate one standard error from the mean. Different letters indicate treatments that significantly differ from each other using a post-hoc Tukey's analysis $(\alpha<0.05)$. 


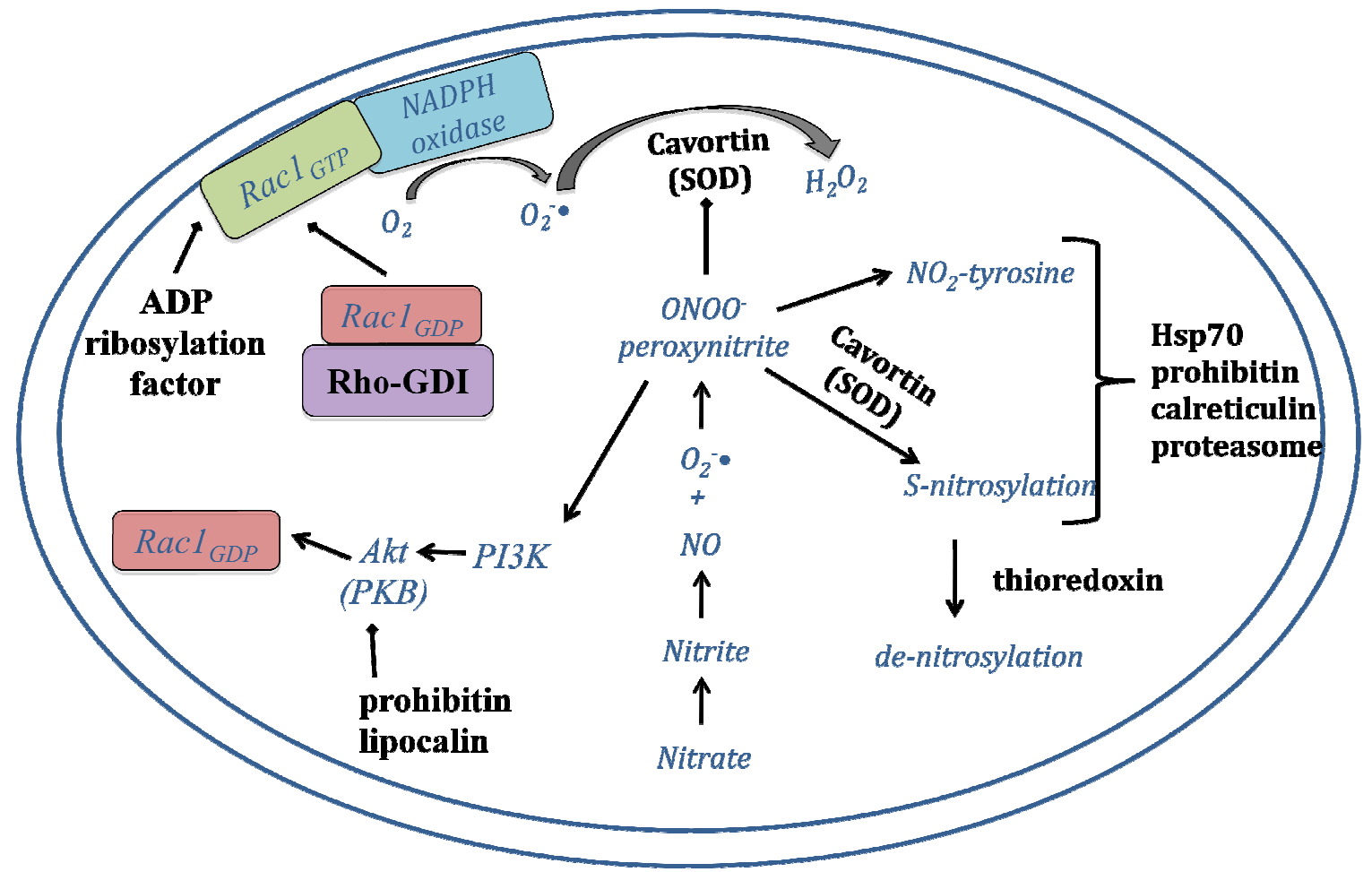

Figure 4: Proposed scenario of the molecular events that are occurring in response to acute nitrate exposure in gill tissue of the Pacific oyster, C. gigas. Proteins we identified are shown in italics (not all proteins are included). Diamond ends indicate an inhibiting activity. For more details see text. 


\section{REFERENCES}

1. Vitousek PM, et al. (1997) human alteration of the global nitrogen cycle: sources and consequences. Ecological Applications 7:737-750.

2. Smith VH (2003) Eutrophication of freshwater and coastal marine ecosystems: a global problem. Environmental Science and Pollution Research 10:126-139.

3. Camargo JA \& Alonso A (2006) Ecological and toxicological effects of inorganic nitrogen pollution in aquatic ecosystems: A global assessment. Environ Int 32(6):831-849.

4. Rabalais NN (2002) Nitrogen in aquatic ecosystems. Ambio 31:102-112.

5. Jensen FB (2003) Nitrite disrupts multiple physiological functions in aquatic animals. Comparative Biochemistry and Physiology 135A:9-24.

6. Camargo JA, Alonso A, \& Salamanca A (2005) Nitrate toxicity to aquatic animals: a review with new data for freshwater invertebrates. Chemosphere 58(9):1255-1267.

7. Alonso A \& Camargo JA (2003) Short-term toxicity of ammonia, nitrite, and nitrate to the aquatic snail Potamopyrgus antipodarum (Hydrobiidae, Mollusca). Bull Environ Contam Toxicol 70(5):1006-1012.

8. Cheng S-Y \& Chen J-C (2002) Study on the oxyhemocyanin, deoxyhemocyanin, oxygen affinity and acid-base balance of Marsupenaeus japonicus following exposure to combined elevated nitrite and nitrate. Aquatic Toxicology 61:181-193.

9. Stormer J, Jensen FB, \& Rankin JC (1996) Uptake of nitrite, nitrate and bromide in rainbow trout, Oncorhynchus mykiss: effects on ionic balance. Canadian Journal of Fisheries and Aquatic Sciences 53:1943-1950.

10. Withers PC (1992) Comparative Animal Physiology (Brooks Cole, Pacific Grove); p 1088.

11. Scott G \& Crunkilton RL (2000) Acute and chronic toxicity of nitrate to fathead minnows (Pimephales promelas), Cerodaphnia dubia and Daphnia magna. Environmental Toxicology and Chemistry 19:2918-2922.

12. Jansson EA, et al. (2008) A mammalian functional nitrate reductase that regulates nitrite and nitric oxide homeostasis. Nat Chem Biol 4(7):411-417.

13. Klotz LO, Schroeder P, \& Sies H (2002) Peroxynitrite signaling: receptor tyrosine kinases and activation of stress-responsive pathways. Free Radic Biol Med 33(6):737-743. 
14. Hedgecock D, Gaffney PM, Goulletquer P, Guo X, Reece K, \& Warr GW (2005) The case for sequencing the Pacific oyster genome Journal of Shellfish Research 24:429-441.

15. Akerstrom B, Flower DR, \& Salier JP (2000) Lipocalins: unity in diversity. Biochim Biophys Acta 1482(1-2):1-8.

16. Wittmann J, Hol EM, \& Jack HM (2006) hUPF2 silencing identifies physiologic substrates of mammalian nonsense-mediated mRNA decay. Mol Cell Biol 26(4):1272-1287.

17. Arumugam M, Romestand $B$, Torreilles $J, \&$ Roch $P(2000)$ In vitro production of superoxide and nitric oxide (as nitrite and nitrate) by Mytilus galloprovincialis haemocytes upon incubation with PMA or laminarin or during yeast phagocytosis. Eur J Cell Biol 79(7):513-519.

18. Gourdon I, Guerin MC, Torreilles J, \& Roch P (2001) Nitric oxide generation by hemocytes of the mussel Mytilus galloprovincialis. Nitric Oxide 5(1):1-6.

19. Tafalla C, Novoa B, \& Figueras A (2002) Production of nitric oxide by mussel (Mytilus galloprovincialis) hemocytes and effect of exogenous nitric oxide on phagocytic functions. Comp Biochem Physiol B Biochem Mol Biol 132(2):423-431.

20. Villamil L, Gomez-Leon J, \& Gomez-Chiarri M (2007) Role of nitric oxide in the defenses of Crassostrea virginica to experimental infection with the protozoan parasite Perkinsus marinus. Dev Comp Immunol 31(10):968-977.

21. Hoshi T \& Heinemann S (2001) Regulation of cell function by methionine oxidation and reduction. $J$ Physiol 531(Pt 1):1-11.

22. Vogt W (1995) Oxidation of methionyl residues in proteins: tools, targets, and reversal. Free Radic Biol Med 18(1):93-105.

23. Schopfer FJ, Baker PR, \& Freeman BA (2003) NO-dependent protein nitration: a cell signaling event or an oxidative inflammatory response? Trends Biochem Sci 28(12):646-654.

24. Hess DT, Matsumoto A, Kim SO, Marshall HE, \& Stamler JS (2005) Protein Snitrosylation: purview and parameters. Nat Rev Mol Cell Biol 6(2):150-166.

25. Nakamura $\mathbf{H}$ (2005) Thioredoxin and its related molecules: update 2005. Antioxid Redox Signal 7(5-6):823-828.

26. Scotti PD, Dearing SC, \& Greenwood DR (2007) Characterization of carvortin, the major haemolymph protein of the Pacific osyter (Crassostrea gigas). New Zealand Journal of Marine and Freshwater Research 41:91-101. 
27. Nakamura T \& Lipton SA (2007) Molecular mechanisms of nitrosative stressmediated protein misfolding in neurodegenerative diseases. Cell Mol Life Sci 64(13):1609-1620.

28. Liu H, Bowes RC, van de Water B, Sillence C, Nagelkerke JF, \& Stevens JL (1997) Endoplasmic reticulum chaperones GRP78 and calreticulin prevent oxidative stress, $\mathrm{Ca} 2+$ disturbances, and cell death in renal epithelial cells. J Biol Chem 272(35):21751-21759.

29. Steglich G, Neupert $W, \&$ Langer T (1999) Prohibitins regulate membrane protein degradation by the m-AAA protease in mitochondria. Mol Cell Biol 19(5):3435-3442.

30. Schleicher M, Schleicher M, Shepherd BR, Suarez Y, Fernandez-Hernando C, Yu J, Pan Y, Acevedo LM, Shadel GS, \& Sessa WC (2008) Prohibitin-1 maintains the angiogenic capacity of endothelial cells by regulating mitochondrial function and senescence. J Cell Biol 180(1):101-112.

31. Zhang J, Wu Y, Zhang Y, Leroith D, Bernlohr DA, Chen X (2008) The role of lipocalin 2 in the regulation of inflammation in adipocytes and macrophages. $M o l$ Endocrinol 22(6):1416-1426.

32. Gwira JA, Wei F, Ishibe S, Ueland JM, Barasch J, Cantley LG (2005) Expression of neutrophil gelatinase-associated lipocalin regulates epithelial morphogenesis in vitro. J Biol Chem 280(9):7875-7882.

33. Montfort WR, Weichsel A, \& Andersen JF (2000) Nitrophorins and related antihemostatic lipocalins from Rhodnius prolixus and other blood-sucking arthropods. Biochim Biophys Acta 1482(1-2):110-118.

34. Gregg D, Rauscher FM, \& Goldschmidt-Clermont PJ (2003) Rac regulates cardiovascular superoxide through diverse molecular interactions: more than a binary GTP switch. Am J Physiol Cell Physiol 285(4):C723-734.

35. Babior BM, Lambeth JD, \& Nauseef W (2002) The neutrophil NADPH oxidase. Arch Biochem Biophys 397(2):342-344.

36. Vignais PV (2002) The superoxide-generating NADPH oxidase: structural aspects and activation mechanism. Cell Mol Life Sci 59(9):1428-1459.

37. Abid MR, et al. (2001) Vascular endothelial growth factor induces manganesesuperoxide dismutase expression in endothelial cells by a Rac1-regulated NADPH oxidase-dependent mechanism. FASEB J 15(13):2548-2550.

38. Li JM \& Shah AM (2004) Endothelial cell superoxide generation: regulation and relevance for cardiovascular pathophysiology. Am J Physiol Regul Integr Comp Physiol 287(5):R1014-1030. 
39. Fang FC (2004) Antimicrobial reactive oxygen and nitrogen species: concepts and controversies. Nat Rev Microbiol 2(10):820-832.

40. MacMillan-Crow LA, Crow JP, Kerby JD, Beckman JS, \& Thompson JA (1996) Nitration and inactivation of manganese superoxide dismutase in chronic rejection of human renal allografts. Proc Natl Acad Sci U S A 93(21):11853-11858.

41. D'Souza-Schorey C \& Chavrier $P$ (2006) ARF proteins: roles in membrane traffic and beyond. Nat Rev Mol Cell Biol 7(5):347-358.

42. Walsh CT (2006) Posttranslational modification of proteins: Expanding nature's inventory (Roberts and Company Publishers, Englewood, Colorado); p 490.

43. McDonagh B \& Sheehan D (2007) Effect of oxidative stress on protein thiols in the blue mussel Mytilus edulis: proteomic identification of target proteins. Proteomics 7(18):3395-3403.

44. Boshans RL, Szanto S, van Aelst L, \& D'Souza-Schorey C (2000) ADP-ribosylation factor 6 regulates actin cytoskeleton remodeling in coordination with Rac1 and RhoA. Mol Cell Biol 20(10):3685-3694.

45. Silacci P, et al. (2004) Gelsolin superfamily proteins: key regulators of cellular functions. Cell Mol Life Sci 61(19-20):2614-2623.

46. Arcaro A (1998) The small GTP-binding protein Rac promotes the dissociation of gelsolin from actin filaments in neutrophils. J Biol Chem 273(2):805-813.

47. Labreuche $Y$, et al. (2006) Cellular and molecular hemocyte responses of the Pacific oyster, Crassostrea gigas, following bacterial infection with Vibrio aestuarianus strain 01/32. Microbes Infect 8(12-13):2715-2724.

48. Bramble LH \& Anderson RS (1999) Lack of involvement of reactive oxygen species in the bacterial activity of Crassostrea virginica haemocytes in contrast to Morone saxatilis phagocytes. Fish \& Shellfish Immunology 9:109-123.

49. Tanguy A, Guo X, \& Ford SE (2004) Discovery of genes expressed in response to Perkinsus marinus challenge in Eastern (Crassostrea virginica) and Pacific (C. gigas) oysters. Gene 338(1):121-131.

50. Benjamin N \& Dykhuizen R (1999) Nitric Oxidation and Infection, ed Fang FC (Kluwer Academic/Plenum Publisher, New York), pp 215-230.

51. Malhalm SK, et al. (2009) Summer mortality of the pacific oyster, Crassostrea gigas, in the Irish Sea: The influence of temperature and nutrients on health and survival. Aquaculture 287:128-138. 
52. Berth M, Moser FM, Kolbe M, \& Bernhardt J (2007) The state of the art in the analysis of two-dimensional gel electrophoresis images. Appl Microbiol Biotechnol 76(6):1223-1243.

53. Bandow JE, et al. (2008) Improved image analysis workflow for 2-D gels enables large-scale 2-D gel-based proteomics studies--COPD biomarker discovery study. Proteomics 8(15):3030-3041.

54. Drabik A, Noga M, Macht M, \& Silberring J (2008) Protein identification by Mass spectrometry. Proteomics: Introduction to Methods and Applications, eds Kraj A \& Silberring J (John Wiley \& Sons, Hoboken), pp 123-141. 